\title{
Genetic Associations Analysis for Fruit Yield and Its Contributing Traits of Indeterminate Tomato (Solanum lycopersicum L.) Germplasm under Open Field Condition
}

\author{
Om Prakash Meena ${ }^{1,2}$ \& Vijay Bahadur ${ }^{1}$ \\ ${ }^{1}$ Department of Horticulture, Allahabad School of Agriculture, Sam Higginbottom Institute of Agriculture, \\ Technology and Sciences, Allahabad, India \\ ${ }^{2}$ Department of Vegetable Science, Punjab Agricultural University, Ludhiana, Punjab, India \\ Correspondence: Om Prakash Meena, Department of Vegetable Science, COA, Punjab Agricultural University, \\ Ludhiana-141 004, Punjab, India. Tel: 91-946-119-4116. E-mail: chandrawatop2@gmail.com
}

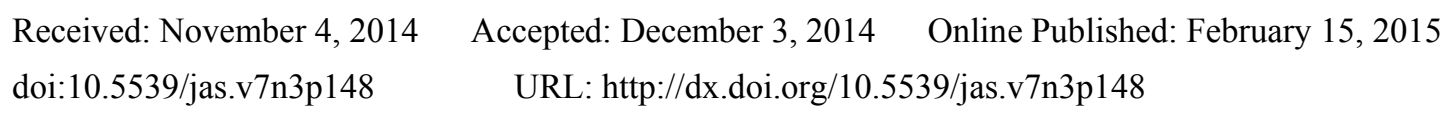

\begin{abstract}
The study was initiated to generate genetic information on characters associations for tomato germplasm under open field condition. Nineteen indeterminate tomato germplasm were evaluated to estimate the nature and magnitude of associations of different characters with fruit yield and among themselves at Vegetable Research Farm, Department of Horticulture, SHIATS, Allahabad (India) during 2012-2013. The experiment was conducted using a Randomized Complete Block Design (RCBD) with three replications. Estimates of genetic parameters revealed that fruit yield was significantly and positively correlated with number of flowers per plant $(0.2894$ and 0.2891$)$ followed by number of fruits per plant $(0.4480$ and 0.4486$)$ and fruit weight $(0.6223$ and $0.6230)$ at genotypic and phenotypic level, respectively, strong association of these traits revealed that the selection based on these traits would ultimately improve the fruit yield and it is also suggested that hybridization of genotypes possessing combination of above characters is most useful for obtaining desirable high yielding segregation. In order to obtain a clear picture of the inter relationship between fruit yield per plant and its components, direct and indirect effects were measured using path coefficient analysis. Fruit weight had a very high positive direct genotypic and phenotypic effect 0.9566 and 0.9442 , respectively on fruit yield per plant followed by number of flowers per plant, fruit set per cent, number of fruits per plant, TSS ${ }^{\circ}$ Brix, plant height, radial diameter of fruit, leaf curl incidence per cent and days to $50 \%$ flowering. The characters showed high direct effect on yield per plant indicated that direct selection for these traits might be effective and there is a possibility of improving yield per plant through selection based on these characters. Residual effect was considerably low (0.0611 and 0.0751) which indicated that characters included in this study explained almost all variability towards yield.
\end{abstract}

Keywords: correlation coefficient, path analysis, tomato (Solanum lycopersicum L.), yield, yield components

\section{Introduction}

Tomato (Solanum lycopersicum L. Syn. Lycopersicon esculentum Mill., $2 \mathrm{n}=2 \mathrm{x}=24$ ) is one of the most important and popular vegetables in the world because of its wider adaptability, high yielding potential and suitability for variety of uses in fresh as well as processed food industries (He et al., 2003; Nwosu et al., 2014). It belongs to the family Solanaceae and is native of Peru Equador region (Jenkins, 1948; Rick, 1969) and is normally a self-pollinated crop. In India, tomato occupies an area of 0.87 million hectares with a production of 17.50 million tonnes and productivity of 20.11 tonnes per hectare (FAO, 2012). As a cash crop, it has great demand in the international market (Hannan et al., 2007a; Solieman et al., 2013). Tomatoes are an excellent source of minerals and vitamins (Sainju et al., 2003; Naika et al., 2005; Akinfasoy et al., 2011). Its vitamin C content is particularly high (Kanyomeka \& Shivute, 2005). Tomato's fruit is consumed in providing salads and cookies. In addition, it is used to can, paste, ketchup, sauce, puree and fruit juice (Maitidevi \& Kathmandu, 2008). Tomato soup is good remedy for patients suffering from constipation and very good appetizer (Kalloo et al., 2001). During ripening, there is a 500 fold increase in the level of lycopene in tomato fruit (Bai \& Lindhot, 2007). Increased lycopene has proven nutritional value as an antioxidant that is associated with a low incidence of certain forms of human 
cancer (Giovannucci et al., 2002; Bai \& Lindhot, 2007). Tomato is grown as an annual or short lived perennial herbaceous plant. It has taproot and growth habit of the plant is determinate, semi-determinate and indeterminate (Reddy et al., 2013).

The approaches to make significant improvement in tomato production require information regarding nature and magnitude of genetic variation in quantitative traits (Adunga \& Labuschangne, 2003; Bello \& Olaoye, 2009; Kaushik et al., 2011) and their interrelationships in the available germplasm, which are important pre-requisites for a systematic breeding program (Al-Aysh et al., 2012). Selection for yield based on multiple traits is always better than selection based on yield alone (Muhammad et al., 2003; Bello et al., 2010). Yield is a quantitative character controlled by many genes (Lungu, 1978). Adequate knowledge about the magnitude and degree of association of yield with its attributing characters or components is of great importance to breeders. Using these components, breeders would understand strength of correlated traits that would assists in decision making process to select for simultaneous improvement of more than one character (Sivaprasad, 2008; Monamodi et al., 2013). Cramer and Wehner (1998) indicated that a way about improving yield indirectly is to select for traits that are highly correlated with yield but possess higher heritability. These traits are often referred to as yield components and may include; the number of harvests per plant, number of branches per plant and marketable yield (Rani et al., 2008). According to Lungu (1978) the consideration of yield components in selection is based on the assumption that a strong positive correlation exists between yield and yield components and that these component characters have higher heritability than yield. For this assumption to be valid the changes or increase in yield must be accompanied by change in one or more of the yield components (Rani et al., 2008). However, correlation alone does not provide information on the contribution of related characters, which need the study of cause and effect relationship of different characters among themselves (McGiffen et al., 1994). It has been observed that path coefficient analysis reveals the exact relationship of characters thereby providing more information than simple correlation analysis, suggesting that correlation analysis is a weaker tool compared to path coefficient analysis (Dewey \& Lu, 1959; McGiffen et al., 1994). The technique of path coefficient analysis was developed by Wright (1921) and demonstrated by Dewey and Lu (1959) as a means of separating direct and indirect contribution of various traits. It is a standardized partial regression coefficient analysis. It measures the direct influence of one variable upon another and permits the separation of correlation coefficient into components of direct and indirect effects. The use of this technique has been reported to require cause and effect situation among the variables according to Singh and Chaudhary (1977). Yield components have also been used to improve yield in crops such as wheat (Dewey \& Lu, 1959; Zecevic et al., 2004; Khan \& Dar, 2010), potato (Bhagowati \& Saikia, 2003; Tuncturk \& Çiftci, 2005), brinjal (Thangamani \& Jansirani, 2012; Ahmed et al., 2013), chilli (Ajjapplavara et al., 2005; Ukkund et al., 2007; Jabeen et al., 2009; Sood et al., 2009) and cucumber (AbuSalena \& Dutta, 1988; Yin \& Cui, 1994; Zhang \& Cui, 1994; Cramer \& Wehner, 1998, 2000; Chandra et al., 2010; Arunkumar et al., 2011; Golabadi et al., 2013). According to Singh (2013), understanding the relative contribution of the various component traits to yield could play a significant role in identifying high yielding genotypes from genetically variable populations by providing information on indirect selection for yield. Thus the present investigation was initiated to study both correlation and path coefficient analysis in different indeterminate tomato germplasm, thereby; it is possible to recognize the relationship among various characters of tomato.

\section{Materials and Methods}

\subsection{Experimental Site and Environment}

This study was carried out during the season 2012-13 at Vegetable Research Farm, Department of Horticulture, SHIATS, Allahabad (India). The city is situated at $25^{\circ} 28^{\prime} \mathrm{N}$ latitude and $81^{\circ} 54^{\prime} \mathrm{E}$ longitude and at a mean altitude of $98 \mathrm{~m}$ above sea level. The climate of Allahabad is characterized as humid sub-tropical with an average annual rainfall of $1027 \mathrm{~mm}$ (40.4 inches). The rainfall is monsoonal in nature with around 75\% received during July-September. The mean weekly agro-meteorological observations were recorded during the crop season (Figure 1). 


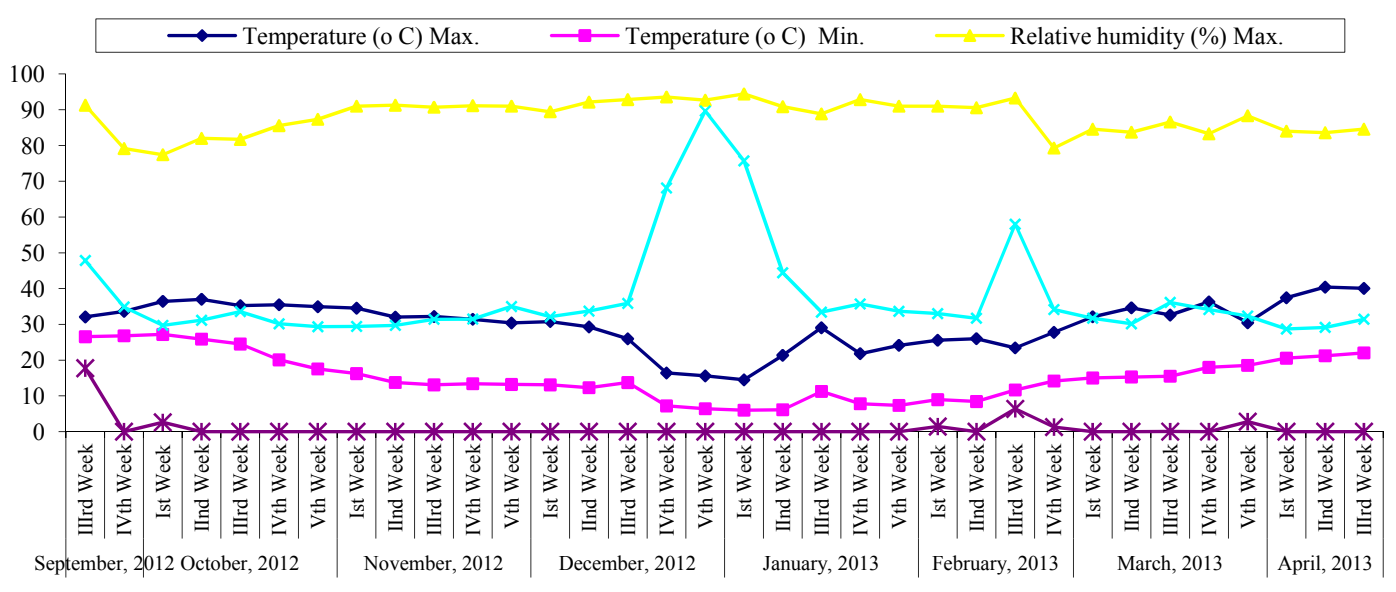

Figure 1. Mean weekly agro-meteorological observations recorded during crop season 2012-2013

\subsection{Experimental Material}

The experimental materials comprised of nineteen indigenous germplasm of indeterminate tomato collected from Indian Institute of Vegetable Research (IIVR), Varanasi and Vegetable Research Station (VRS), JAU, Junagadh, India (Table 1). For raising good and healthy seedlings, the seeds were treated with carbendazim @ $2.0 \mathrm{~g} / \mathrm{kg}$ seed. After that the seeds of nineteen germplasm of tomato were sown in the nursery and their seedlings were transplanted in small plots $(2.0 \mathrm{~m} \times 2.0 \mathrm{~m})$ in open-field where row-to-row and plant-to-plant spacing was $60 \mathrm{~cm}$ $\times 60 \mathrm{~cm}$ that contained 16 plants. The experiment was laid out in a randomized complete block design (RCBD) with three replications. All the recommended agronomic package of practices was followed (like staking, earthing up, irrigation, weeding etc.), as recommended for commercial tomato production.

\subsection{Experimental Data}

The observation were recorded on five randomly selected plants per replication for each germplasm on fifteen quantitative characters viz., plant height $(\mathrm{cm})$, number of branches per plant, number of leaves per plant, days to $50 \%$ flowering, number of flower clusters per plant, number of flowers per plant, number of fruits per plant, fruit set per cent, fruit weight $(\mathrm{g})$, radial diameter of fruit $(\mathrm{mm})$, polar diameter of fruit $(\mathrm{mm})$, fruit yield per plant $(\mathrm{g})$, leaf curl incidence per cent (based on the scale given by Joshi \& Choudhary, 1981), TSS Brix (by using a hand refractometer, Model: ATAGO, Tokyo, Japan) and ascorbic acid (mg/100 g) was estimated using 2,6-dichlorophenol indophenol method as illustrated by AOAC (1975).

\subsection{Stastical Analysis and Estimation of Genetic Parameters}

Data of all the previously mentioned characters were arranged and statistically analyzed, using the standard methods of the randomized complete blocks design as illustrated by Clewer and Scarisbrick (2001), using Co-State Software (2004) computer program for statistics.

Analysis of variance: Analysis of variance was done by the method suggested by Panse and Sukhatme (1985).

Estimation of Correlations: The correlation coefficient analysis among all possible characters combination at phenotypic (rp) and genotypic (rp) level were estimated employing the formulae (Al-Jibourie et al., 1958).

$$
\begin{aligned}
& \text { Phenotypic correlation }=V_{x y(p)}=\frac{C O V_{x y(p)}}{\sqrt{\left[V_{x(p)} \times V_{y(p)}\right]}} \\
& \text { Genotypic correlation }=V_{x y(g)}=\frac{C O V_{x y(g)}}{\sqrt{\left[V_{x(g)} \times V_{y(g)}\right]}}
\end{aligned}
$$

Where:

$C O V_{x y(p)}=$ Phenotypic co-variance between variables $\mathrm{x}$ and $\mathrm{y} ; C O V_{x y(g)}=$ Genotypic co-variance between variables $\mathrm{x}$ and y; $V_{x(p)}=$ Phenotypic variance for the variable $\mathrm{x} ; V_{x(g)}=$ Genotypic variance for the variable $\mathrm{x}$; $V_{y(p)}=$ Phenotypic variance for the variable y; $V_{y(g)}=$ Genotypic variance for the variable $\mathrm{y}$.

Significance of correlation coefficient at both phenotypic and genotypic levels was tested by comparing table ' $r$ ' value with obtained value. 
Path Coefficient Analysis: Path coefficient is a standardized partial regression coefficient and as such it is a measure of direct and indirect effect of a set variable (component characters) as a dependent variable such as fruit yield. The estimates of direct and indirect effect of component characters on fruit yield were computed using appropriate correlation coefficient of different component characters as suggested by Wright (1921) and elaborated by Dewey and Lu (1959). Thus, the correlation coefficient of any character with fruit yield was split into direct and indirect effects adopting the standard formula.

$$
r_{i y}=r_{1 i} P_{1}+r_{2 i} P_{2}+r_{3 i} P_{3}+\ldots+r_{n i} P_{n}+\ldots r_{i i} P_{1}
$$

Where:

$r_{i y}=$ Correlation of the $i t h$ character with fruit yield; $r_{n i}=$ Correlation between nth character with ith character; $n$ $=$ Number of independent variables (component characters); $P_{i}=$ Direct effect of ith character on fruit yield.

Direct effects of different component character on fruit yield were obtained by solving the following equations.

$$
r_{i y}=\left[P_{I}\right]\left[r_{i j}\right] \text {, which can also be rearranged as }\left[P_{I}\right]=\left[r_{i j}\right]^{-1}\left[r_{i j}\right]
$$

Where:

$\left[P_{I}\right]=$ Matrix of direct effect;

$\left[r_{i j}\right]=$ Matrix of correlation coefficients among all the $\mathrm{n}$ components characters; $\left[r_{i y}\right]=$ Matrix of correlation of all component characters with fruit yield; $r_{i l}=$ Indirect effect of ith character on fruit yield through first characters.

The residual effect was obtained by the following formula.

$$
\text { Residual effect }=P R=\sqrt{1}-P_{i} r_{i y}
$$

Where: $P_{i}$ and $r_{i y}$ are as given above.

\section{Results and Discussion}

Mean square values of Analysis of Variance (ANOVA) showed highly significant difference among the tested germplams for all the characters studied. The significant variation among the germplasm revealed that presence of adequate variability which can be exploited through selection (Table 2). Similar results were noticed by Barman et al. (1995); Singh and Raj (2004); Singh and Cheema (2005); Hidayatullah et al. (2008); Basavaraj et al. (2010); Kaushik et al. (2011); Dar and Sharma (2011); Jilani et al. (2013); Monamodi et al. (2013).

The yield is a complex character that is controlled by quite a number of factors. Hence, the degree of association of these complex characters formed the basis for yield evaluations and correlation coefficient analysis measures the extent of closeness of the component traits. The phenotypic and genotypic correlation among the yield and yield components in tomato are presented in Table 3. Significant correlation of characters suggested that there is much scope for direct and indirect selection for further improvement. Genotypic correlation coefficient provides measures of genetic association between traits and thus helps to identify the more important as well as less important traits to be considered in breeding programs. Similar types of findings were also reported by Tiwari and Upadhyay (2011). In general, the estimate of genotypic correlation coefficient was higher than their corresponding phenotypic correlation coefficients. This can be interpreted as a strong inherent genotypic relationship between characters studied, through their phenotypic expression was impeded by environmental influence. The present findings are in conformity with Harer et al. (2003); Kumar et al. (2003); Golani et al. (2007); Islam et al. (2010); Dar et al. (2011); Al-Aysh et al. (2012); Souza et al. (2012); Tasisa et al. (2012). The nature of genotypic correlation was similar to phenotypic correlation. However, in some cases correlation coefficients at genotypic level were significant, while at phenotypic level same were found to be non-significant (Kumari \& Sharma, 2013).

Basically yield is the main character with which all other characters are positively or negatively correlated. In the present investigation, fruit yield per plant exhibited significant and positively correlated with number of flowers per plant $(0.2894$ and 0.2891$)$, number of fruits per plant $(0.4480$ and 0.4486$)$ and fruit weight $(0.6223$ and $0.6230)$ at genotypic and phenotypic level, respectively, indicated that these traits are important for selection view point for getting high fruit yield in tomato. Similar results supported by the findings of Anjum et al. (2009); Maurya et al. (2011); Kumari and Sharma (2013); Monamodi et al. (2013); Saleem et al. (2013); Khapte and Jansirani (2014); Kumar et al. (2014) for number of fruits per plant and fruit weight; Dhankhar and Dhankar (2006); Hannan et al. (2007b); Souza et al. (2012) for fruit number per plant; Susic et al. (2002) for fruit weight. 
Table 1. Collection of different germplasm

\begin{tabular}{|c|c|c|c|c|c|}
\hline S. No. & Name of Germplasm & Source & S. No. & Name of Germplasm & Source \\
\hline 1. & 2011/TOINDVAR-1 & IIVR, Varanasi & 11. & EC 620430 & IIVR, Varanasi \\
\hline 2. & 2011/TOINDVAR-2 & IIVR, Varanasi & 12. & EC 620432 & IIVR, Varanasi \\
\hline 3. & 2011/TOINDVAR-3 & IIVR, Varanasi & 13. & EC 620434 & IIVR, Varanasi \\
\hline 4. & 2011/TOINDVAR-4 & IIVR, Varanasi & 14. & EC 620437 & IIVR, Varanasi \\
\hline 5. & 2011/TOINDVAR-5 & IIVR, Varanasi & 15. & EC 620449 & IIVR, Varanasi \\
\hline 6. & 2012/TOINDVAR-1 & IIVR, Varanasi & 16. & AJETA-32 & IIVR, Varanasi \\
\hline 7. & 2012/TOINDVAR-2 & IIVR, Varanasi & 17. & ARKA VIKAS & IIVR, Varanasi \\
\hline 8. & 2012/TOINDVAR-3 & IIVR, Varanasi & 18. & ANGOOR LATA & IIVR, Varanasi \\
\hline 9. & 2012/TOINDVAR-4 & IIVR, Varanasi & 19. & 2012/GT-1 & VRS, JAU, Junagadh \\
\hline 10. & EC 620421 & IIVR, Varanasi & & & \\
\hline
\end{tabular}

Table 2. Analysis of variance for 15 characters of indeterminate tomato germplasm

\begin{tabular}{lllll}
\hline & & \multicolumn{3}{c}{ Mean Sum of Squares } \\
\cline { 3 - 5 } S. No. & Source of Variance/ Characters & $\begin{array}{l}\text { Replication } \\
\text { (d.f. }=2)\end{array}$ & $\begin{array}{l}\text { Treatment } \\
(\text { d.f. }=18)\end{array}$ & $\begin{array}{l}\text { Error } \\
\text { (d.f. }=36)\end{array}$ \\
\hline 1. & Plant height at 120DAT $(\mathrm{cm})$ & 1.69 & $1331.66^{* *}$ & 0.46 \\
2. & No. of branches/plant at 120DAT & 0.16 & $11.65^{* *}$ & 0.20 \\
3. & No. of leaves/plant at 120DAT & 0.34 & $461.38^{* *}$ & 0.60 \\
4. & Days to 50\% flowering & 0.006 & $153.96^{* *}$ & 0.31 \\
5. & No. of flower clusters/plant & 0.04 & $24.02^{* *}$ & 0.06 \\
6. & No. of flowers/plant & 0.37 & $1159.45^{* *}$ & 2.06 \\
7. & Average no. of fruits/plant & 0.08 & $228.04^{* *}$ & 0.28 \\
8. & Fruit set $(\%)$ & 0.07 & $129.30^{* *}$ & 0.56 \\
9. & Average fruit weight $(\mathrm{g})$ & 1.43 & $225.66^{* *}$ & 0.36 \\
10. & Radial diameter of fruit $(\mathrm{mm})$ & 0.42 & $172.18^{* *}$ & 0.12 \\
11. & Polar diameter of fruit $(\mathrm{mm})$ & 0.23 & $70.06^{* *}$ & 0.39 \\
12. & Fruit yield/plant $(\mathrm{g})$ & 5206.96 & $912915.31^{* *}$ & 2657.22 \\
13. & Leaf curl incidence $(\%)$ & 0.004 & $257.55^{* *}$ & 0.02 \\
14. & TSS ${ }^{\circ}$ Brix & 0.01 & $1.33^{* *}$ & 0.01 \\
15. & Ascorbic Acid $(\mathrm{mg} / 100 \mathrm{~g})$ & 0.17 & $333.75^{* *}$ & 0.39 \\
\hline
\end{tabular}

Note. ${ }^{* *}$ Significant at $0.1 \%$; d.f. $=$ degree of freedom. 
Table 3. Estimates of genotypic and phenotypic correlation among different traits of indeterminate tomato germplasm

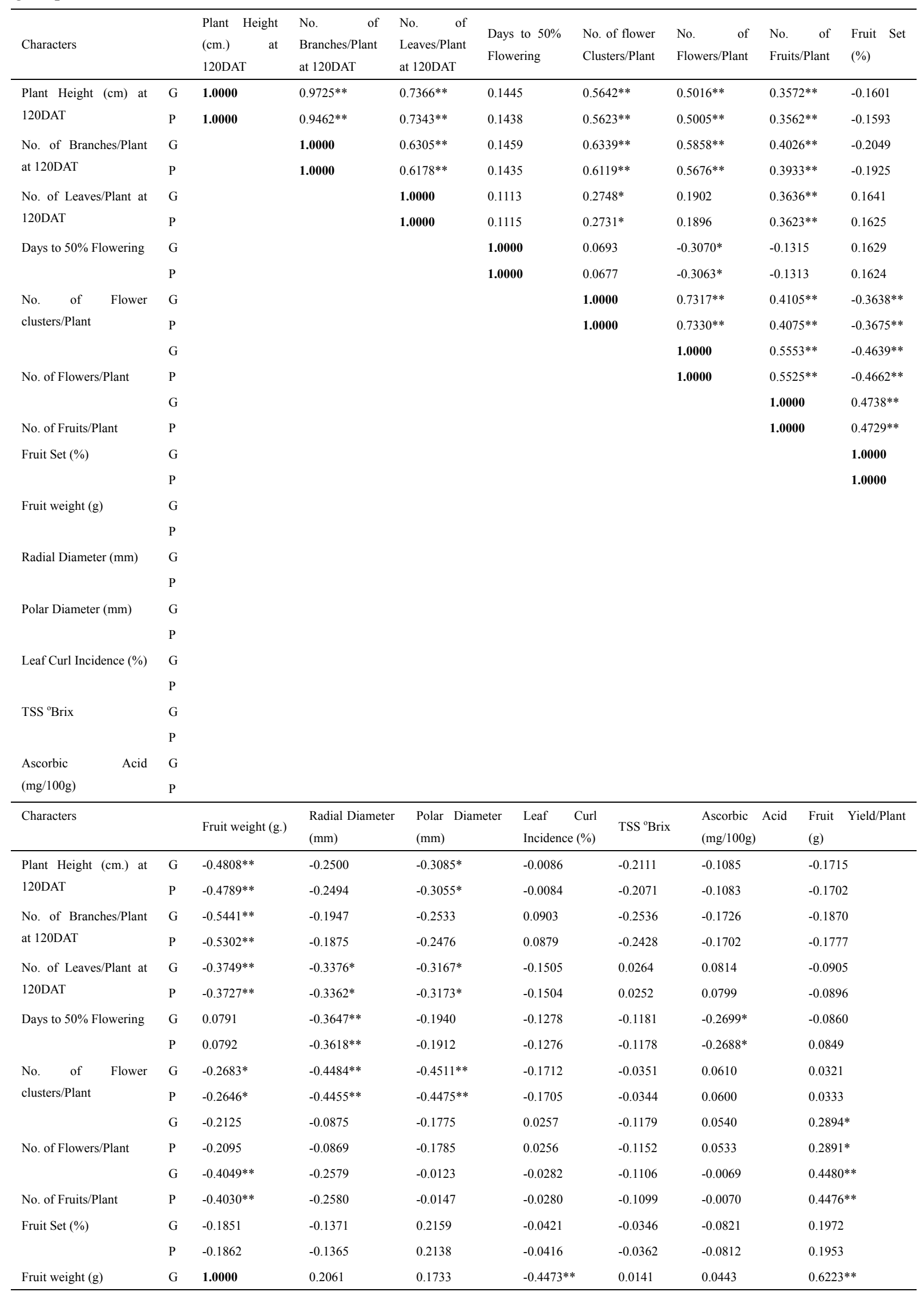




\begin{tabular}{|c|c|c|c|c|c|c|c|c|}
\hline & $\mathrm{P}$ & 1.0000 & 0.2055 & 0.1682 & $-0.4460 * *$ & 0.0156 & 0.0434 & $0.6220^{* *}$ \\
\hline \multirow[t]{2}{*}{ Radial Diameter (mm) } & G & & 1.0000 & $0.3323 *$ & $0.4324 * *$ & -0.1352 & -0.0388 & 0.1026 \\
\hline & $\mathrm{P}$ & & 1.0000 & $0.3288^{*}$ & $0.4320 * *$ & -0.1331 & -0.0386 & 0.1015 \\
\hline \multirow[t]{2}{*}{ Polar Diameter (mm) } & G & & & 1.0000 & 0.0748 & $-0.3628 * *$ & $-0.4116^{* *}$ & 0.1946 \\
\hline & $\mathrm{P}$ & & & 1.0000 & 0.0741 & $-0.3555^{* *}$ & $-0.4050^{* *}$ & 0.1868 \\
\hline \multirow[t]{2}{*}{ Leaf Curl Incidence (\%) } & G & & & & 1.0000 & $-0.3998 * *$ & $-0.3329 *$ & $-0.3936 * *$ \\
\hline & $\mathrm{P}$ & & & & 1.0000 & $-0.3935^{* *}$ & $-0.3324^{*}$ & $-0.3916 * *$ \\
\hline \multirow[t]{2}{*}{ TSS ${ }^{\circ} \mathrm{Brix}$} & G & & & & & 1.0000 & $0.8995 * *$ & -0.0793 \\
\hline & $\mathrm{P}$ & & & & & 1.0000 & $0.8831 * *$ & -0.0780 \\
\hline \multirow{2}{*}{$\begin{array}{l}\text { Ascorbic } \\
(\mathrm{mg} / 100 \mathrm{~g})\end{array}$} & G & & & & & & 1.0000 & 0.0489 \\
\hline & $\mathrm{P}$ & & & & & & 1.0000 & 0.0475 \\
\hline
\end{tabular}

Note. ${ }^{*} \&{ }^{* *}$ significant at $5 \%$ and $1 \%$ level of significance, respectively. $\mathrm{G}=$ genotypic correlation; $\mathrm{P}=$ phenotypic correlation.

Plant height showed significant and positive association with number of branches per plant (0.9725 and 0.9462), number of leaves per plant ( 0.7366 and 0.7343$)$ and number of flower clusters per plant (0.5642 and 0.5623$)$, number of flowers per plant ( 0.5016 and 0.5005$)$ and number of fruits per plant ( 0.3572 and 0.3562$)$ at genotypic and phenotypic level, respectively. The results indicated that as the plant height increases all those characters would also increase. Similar kind of results were reported by Islam et al. (2010) for number of branches per plant and number of flowers per plant; Mahapatra et al. (2013) for number of branches per plant, number of flower clusters per plant and number of fruits per plant; Ogwulumba and Ugwuoke (2013) for number of leaves per plant and number of fruits per plant. Plant height showed negative significant correlation with fruit weight and polar diameter of fruit, indicated that as the plant height increases, fruit weight and polar diameter of fruit would decrease. These results are in confirmation with the findings of Islam et al. (2010).

On the other hand number of flowers per plant showed significant and positive association with plant height (0.5016 and 0.5005), number of branches per plant $(0.5858$ and 0.5676$)$, number of flower clusters per plant (0.7317 and 0.7330), number of fruits per plant (0.5553 and 0.5525) and fruit yield per plant (0.2894 and 0.2891) Similar types of findings were also reported by Islam et al. (2010) for number of fruits per plant and yield per plant.

The trait, number of fruits per plant showed significant and positive association with plant height $(0.3572$ and $0.3562)$, number of branches per plant (0.4026 and 0.3933), number of leaves per plant $(0.3636$ and 0.3623$)$, number of flower clusters per plant (0.4105 and 0.4075$)$, number of flowers per plant (0.5553 and 0.5525$)$, fruit set per cent ( 0.4738 and 0.4729$)$ and fruit yield per plant (0.4480 and 0.4476$)$ at genotypic and phenotypic level, respectively. The result was in full agreement with some earlier studies by Moya et al. (1996); Singh et al. (1997); Harer et al. (2003); Haydar et al. (2007); Islam et al. (2010) for fruit yield per plant; Khapte and Jansirani (2014) for number of branches per plant, number of flower truss per plant and fruit set per cent; Izge et al. (2012) for number of flower clusters, number of leaves per plant and plant height. The significant and negative association was observed with fruit weight $(-0.4049$ and -0.4030$)$. The negative correlation of fruit number with fruit weight means that if there are more fruits in a truss, the tomato fruit weight will tend to be smaller as fruits will compete for space for attachment in a truss as well as for the nutrients. This association was expected since it appears reasonable that as more fruits are produced per truss, the plant will have more fruits and the total weight of fruits per plant will increase as well (Hidayatullah et al., 2008; Monamodi et al., 2013; Buckseth et al., 2012; Kumari \& Sharma, 2013).

Fruit weight showed significant and positive association both at genotypic and phenotypic level with fruit yield per plant $(0.6223$ and 0.6220$)$ which indicated that as the fruit weight increases the fruit yield per plant would increase. The result was in line with findings of various investigators (Prasad \& Rai, 1999; Mohanthy, 2002a, 2002b; Harer et al., 2003). The interesting relationship to note was that of total soluble solids (TSS) which had a negative relationship with most components except with number of leaves per plant, fruit weight and ascorbic acid. This negative relationship with total soluble solids suggests that there may be competition for resources between total soluble solids and other components (Monamodi et al., 2013). Ascorbic acid (mg/100 g.) showed significant and positive association with TSS (0.8995 and 0.8831$)$ at genotypic and phenotypic level.

Path coefficient analysis provides an effective means of partitioning direct or indirect causes of association. As yield is influenced by many factors, selection based on correlation may be misleading because it measures only 
the mutual association between two variables, whereas path coefficient analysis specifically measures the relative importance of different yield components. To find out the direct and indirect effects and to measure the relative importance of causal factors, path coefficient analysis is useful, which permits critical examination of the specific forces acting to produce a given correlation (Bhatt, 1973; Izge et al., 2012).

The results of the present investigation on path coefficient analysis as presented in Table 4 and Figure 2 revealed that fruit weight had a very high positive direct genotypic and phenotypic effect 0.9566 and 0.9442 , respectively on fruit yield per plant followed by number of flowers per plant $(0.7543$ and 0.5071$)$, fruit set per cent $(0.6205$ and 0.3850$)$, number of fruits per plant $(0.2002$ and 0.4387$)$, TSS ${ }^{\circ}$ Brix $(0.1621$ and 0.0684$)$, plant height $(0.1337$ and 0.0131$)$, radial diameter of fruit $(0.0956$ and 0.0882$)$, leaf curl incidence per cent $(0.0306$ and $0.0043)$ and days to $50 \%$ flowering $(0.0266$ and 0.0265$)$. The characters showing high direct effect on yield per plant indicated that direct selection for these traits might be effective and there is a possibility of improving yield per plant through selection based on these characters. The results in accordance with the finding of Dudi and Kalloo (1982); Singh et al. (1989); Hazarika and Das (1998); Sankari (2000); Sharma and Verma (2000); Verma and Sarnaik (2000); Ara et al. (2009); Ghosh et al. (2010); Monamodi et al. (2013); Khapte and Jansirani (2014) for fruit weight and number of fruits per plant; Vikram and Kohli (1998); Bodende (2002); Lakshmi and Mani (2004); Indu Rani et al. (2010); Rani et al. (2008) for fruit weight; Islam and Khan (1991); McGiffen et al. (1994); Padda et al. (1971); Rathod (1997); Dhankar et al. (2001); Mageswari et al. (1999); Yadav and Singh (1998) for number of fruits per plant; Islam et al. (2010) for plant height, flowers per plant, fruits per plant, fruit weight. On the other hand the traits, viz., number of branches per plant, number of leaves per plant, number of flower clusters per plant, polar diameter of fruit, ascorbic acid had negative direct effect toward yield at the genotypic as well as phenotypic level. Anikumar et al. (2003) reported that based on the path coefficient analysis, selection should be based on more number of fruits with higher average fruit weight. Joshi et al. (2004) found that the number of fruits per plant is the most important yield contributing trait.

At both genotypic and phenotypic level plant height exhibited positive indirect effect on fruit yield via number of branches per plant, number of leaves per plant, days to $50 \%$ flowering, number of flower clusters per plant, number of flowers per plant and number of fruits per plant. Similar findings have also been reported by Islam et al. (2010) for flowers per plant, branches per plant and fruits per plant; Saleem et al. (2013) for number of fruits per plant; Tiwari and Upadhyay (2011) for days to 50\% flowering and number of branches per plant. Days to 50 $\%$ flowering exhibited positive indirect effect on fruit yield via plant height, number of branches per plant, number of leaves per plant, number of flower clusters per plant, fruit set per cent and fruit weight. Similar results were obtained by Tiwari and Upadhyay (2011) for fruit weight.

Number of fruits per plant exhibited positive indirect effect on yield through the characters like plant height, number of branches per plant, number of leaves per plant, number of flower clusters per plant, number of flowers per plant and fruit set per cent. Similar results were reported earlier in tomato by Islam et al. (2010) for plant height, branches per plant and flowers per plant; Mahapatra et al. (2013) for plant height, number of primary branches per plant, number of flower clusters per plant. Emphasis should therefore, be given on this trait as one of the most vital yield components for contribution to the final yield. At both genotypic and phenotypic level fruit weight recorded positive indirect effect on yield via days to $50 \%$ flowering, radial diameter of fruit, polar diameter of fruit, TSS and ascorbic acid. Similar results were obtained by Kumar and Dudi (2011) for total soluble solids; Islam et al. (2010) for fruit diameter. From the path analysis it may be pointed out that individual fruit weight might be the most potential yield contributing trait for higher yield of tomato.

TSS ${ }^{\circ}$ Brix exhibited positive indirect effect on fruit yield via number of leaves per plant, fruit weight and ascorbic acid. Supporting evidence could be obtained from the results of Rani et al. (2010) for fruit weight. 
Table 4. Direct (diagonal) and indirect effects of component characters contributing to yield in indeterminate tomato at genotypic and phenotypic level

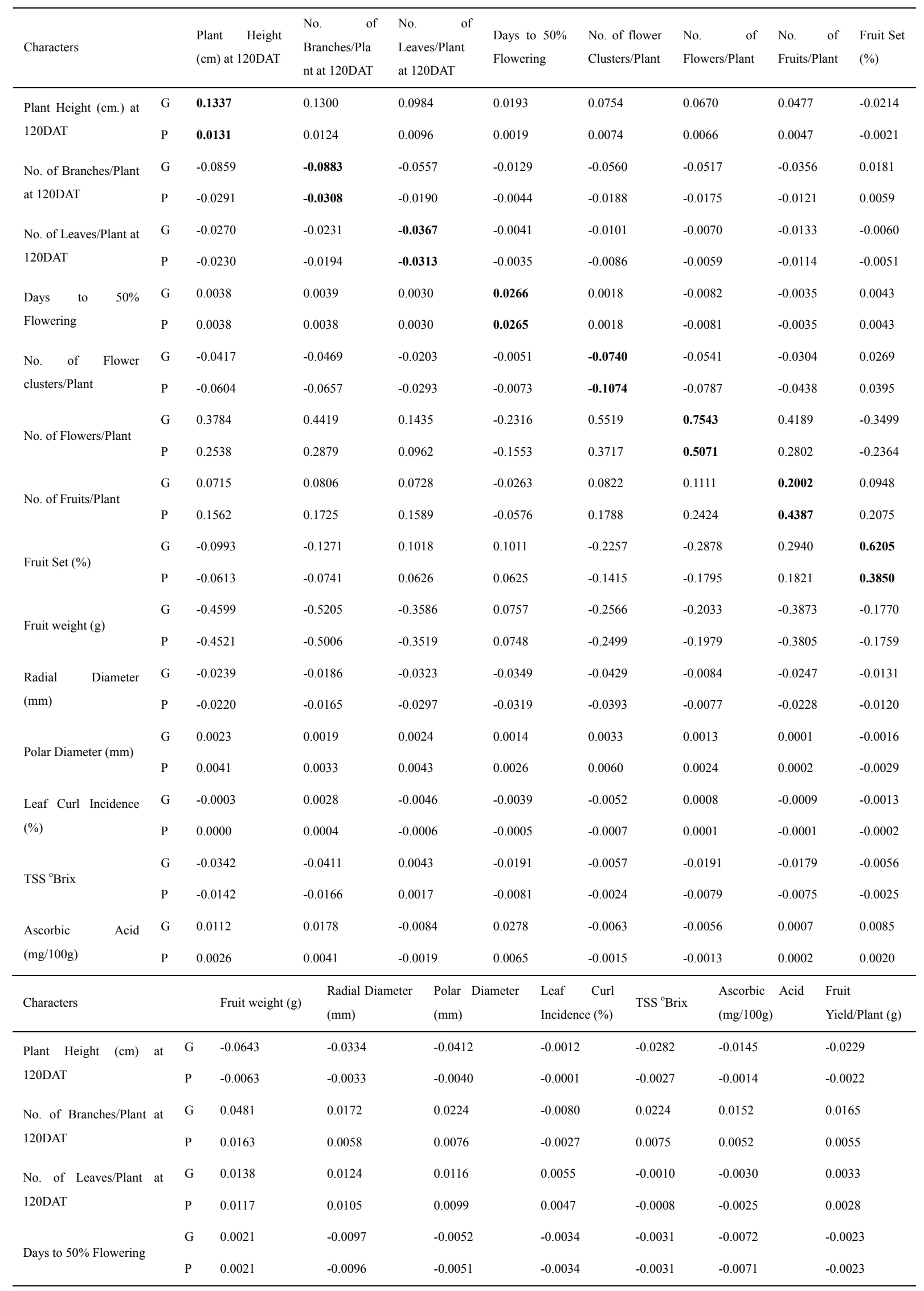




\begin{tabular}{|c|c|c|c|c|c|c|c|c|c|}
\hline No. & Flower & G & 0.0198 & 0.0332 & 0.0334 & 0.0127 & 0.0026 & -0.0045 & -0.0024 \\
\hline clusters/Plant & & $P$ & 0.0284 & 0.0479 & 0.0481 & 0.0183 & 0.0037 & -0.0064 & -0.0036 \\
\hline \multirow{2}{*}{\multicolumn{2}{|c|}{ No. of Flowers/Plant }} & G & -0.1603 & -0.0660 & -0.1339 & 0.0194 & -0.0889 & 0.0407 & 0.2183 \\
\hline & & $\mathrm{P}$ & -0.1063 & -0.0441 & -0.0905 & 0.0130 & -0.0584 & 0.0270 & 0.1466 \\
\hline \multirow{2}{*}{\multicolumn{2}{|c|}{ No. of Fruits/Plant }} & G & -0.0810 & -0.0516 & -0.0025 & -0.0056 & -0.0221 & -0.0014 & 0.0897 \\
\hline & & $P$ & -0.1768 & -0.1132 & -0.0065 & -0.0123 & -0.0482 & -0.0031 & 0.1968 \\
\hline \multirow{2}{*}{\multicolumn{2}{|c|}{ Fruit Set (\%) }} & G & -0.1148 & -0.0851 & 0.1339 & -0.0261 & -0.0215 & -0.0509 & 0.1223 \\
\hline & & $P$ & -0.0717 & -0.0526 & 0.0823 & -0.0160 & -0.0139 & -0.0313 & 0.0752 \\
\hline \multirow{2}{*}{\multicolumn{2}{|c|}{ Fruit weight (g) }} & G & 0.9566 & 0.1972 & 0.1658 & -0.4278 & 0.0135 & 0.0424 & 0.5953 \\
\hline & & $\mathrm{P}$ & 0.9442 & 0.1940 & 0.1588 & -0.4211 & 0.0147 & 0.0410 & 0.5883 \\
\hline \multirow{2}{*}{\multicolumn{2}{|c|}{ Radial Diameter (mm) }} & G & 0.0197 & 0.0956 & 0.0318 & 0.0413 & -0.0129 & -0.0037 & 0.0098 \\
\hline & & $\mathrm{P}$ & 0.0181 & 0.0882 & 0.0290 & 0.0381 & -0.0117 & -0.0034 & 0.0090 \\
\hline \multirow{2}{*}{\multicolumn{2}{|c|}{ Polar Diameter (mm) }} & G & -0.0013 & -0.0025 & -0.0074 & -0.0006 & 0.0027 & 0.0031 & -0.0014 \\
\hline & & $\mathrm{P}$ & -0.0023 & -0.0044 & -0.0135 & -0.0010 & 0.0048 & 0.0055 & -0.0025 \\
\hline \multirow{2}{*}{\multicolumn{2}{|c|}{ Leaf Curl Incidence (\%) }} & G & -0.0137 & 0.0133 & 0.0023 & 0.0306 & -0.0123 & -0.0102 & -0.0121 \\
\hline & & $\mathrm{P}$ & -0.0019 & 0.0019 & 0.0003 & 0.0043 & -0.0017 & -0.0014 & -0.0017 \\
\hline \multirow{2}{*}{\multicolumn{2}{|c|}{ TSS ${ }^{\circ} \mathrm{Brix}$}} & G & 0.0023 & -0.0219 & -0.0588 & -0.0648 & 0.1621 & 0.1458 & -0.0129 \\
\hline & & $P$ & 0.0011 & -0.0091 & -0.0243 & -0.0269 & 0.0684 & 0.0604 & -0.0053 \\
\hline \multirow{2}{*}{\multicolumn{2}{|c|}{ Ascorbic Acid (mg/100g) }} & G & -0.0046 & 0.0040 & 0.0424 & 0.0343 & -0.0926 & -0.1030 & -0.0050 \\
\hline & & $P$ & -0.0011 & 0.0009 & 0.0099 & 0.0081 & -0.0215 & -0.0243 & -0.0012 \\
\hline
\end{tabular}

Note. Residual effect: Genotypic $(\mathrm{G})=0.0611$ and Phenotypic $(\mathrm{P})=0.0751$ (Bold diagonal values are direct effects).

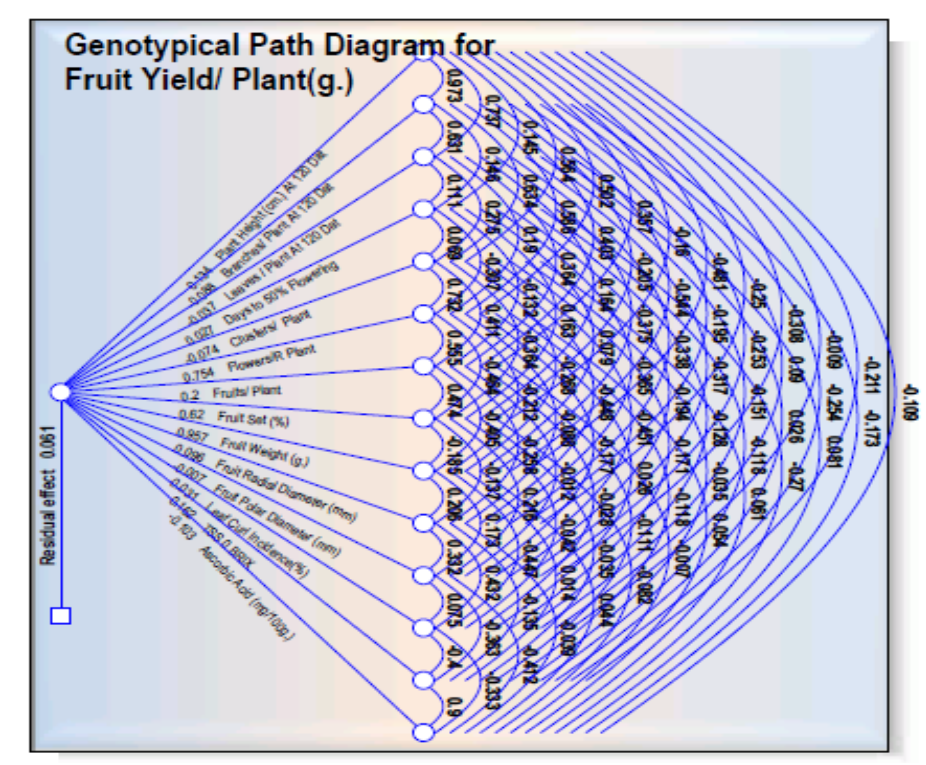

Figure 2. Genotypic path diagram for fruit yield/plant (g)

\section{Conclusion}

In present study, it could be concluded that the traits like; fruit weight, number of flowers per plant and number of fruits per plant showed positive correlation with yield as well as they have direct effect on yield. Hence these traits can be used as selection indices in tomato to bring about the improvement in fruit yield. The residual effect 
of the genotypic and phenotypic path analysis was very less i.e. 0.0611 and 0.0751 , respectively. This indicates that the characters chosen for the present study is the main components of yield and that the variability in yield is accounted by the characters chosen for this investigation to a considerable extent. Correlation and path coefficient studies suggested that the selection should be primarily based on the component characters which exhibited significant positive correlation with yield and also had either direct or indirect effect on yield. This may lead to development of high yielding germplasm in tomato.

\section{Acknowledgements}

The authors are highly grateful to Indian Institute of Vegetable Research, Varanasi and Vegetable Research Station, JAU, Junagadh (India) for providing tomato germplasm for present study.

\section{References}

AbuSalena, S., \& Dutta, O. P. (1988). Interrelationship of yield components in cucumber. Vegetable Science, 15, 79-85.

Adunga, W., \& Labuschangne, M. T. (2003). Association of linseed characters and its variability in different environment. Journal of Agricultural Sciences, 14, 285-296.

Ahmed, N., Singh, S. R., \& Lal, S. (2013). Character association and path analysis in brinjal (Solanum melongena) for yield and yield attributes. Indian Journal of Agricultural Sciences, 83(1), 93-95.

Ajjapplavara, P. S., Patil, S. S., Hosamani, R. M., Patil, A. A., \& Gangaprasad, S. (2005). Correlation and path coefficient analysis in chilli. Karnataka Journal of Agricultural Sciences, 18(3), 748-751.

Akinfasoye, J., Dotun, A., Ogunniyan, J., \& Ajayi, E. O. (2011). Phenotypic relationship among agronomic characters of commercial tomato (Lycopersicum esculentum) hybrids. American-Eurasian Journal of Agronomy, 4(1), 17-22.

Al-Aysh, F., Kutma, H., Serhan, M., Al-Zoubai, A., \& Al-Naseer, M. A. (2012). Genetic analysis and correlation studies of yield and fruit quality traits in tomato (Solanum lycopersicum L.). New York Science Journal, 5(10), 142-145.

Al-Jibourie, H. A., Miller, P. A., \& Robinson, H. F. (1958). Genotypic and environmental variance in an upland cotton cross of interspecific origin. Agronomy Journal, 50, 663-637.

Anikumar, V. R., Thakur, M. C., \& Hedau, N. K. (2003). Correlation and path coefficient analysis in tomato. Annals of Agricultural Research New Series, 24, 175-177.

Anjum, A., Raj, N., Nazeer, A., \& Kahn, S. H. (2009). Genetic variability and selection parameters for yield and quality attributes in tomato. Indian Journal of Horticulture, 66, 73-78.

AOAC. (1975). In W. Horowitz (Ed.), Official Methods of Analysis. Association of Official Analytical Chemists, Washington, DC, USA.

Ara, A., Narayan, R., Ahmed, N., \& Khan, S. H. (2009). Genetic variability and selection parameters for yield and quality attributes in tomato. Indian Journal of Horticulture, 66(1), 73-78.

Arunkumar, K. H., Patil, M. G., Hanchinamani, C. N., Goud, I. S., \& Hiremath, S. V. (2011). Genetic relationship of growth and development traits with fruit yield in F2 population of BGDL $\times$ Hot season of cucumber (Cucumis sativus L.). Karnataka Journal of Agricultural Science, 24, 497-500.

Bai, Y., \& Lindhot, P. (2007). Domestication and breeding of tomatoes: what have we gained and what can we gain in the future. Annals of Botany, 100(5), 1085-1094. http://dx.doi.org/10.1093/aob/mcm150

Barman, D., Sharma, C. K., Singh, I. P., \& Sardana, S. D. L. C. (1995). Genetic variability in exotic lines of tomato (Lycopersicon esculentum Mill.) in off season. International Journal of Tropical Agriculture, 13, 265-268.

Basavaraj, S. N., Hosamani, R. M., \& Patil, B. C. (2010). Genetic variability in tomato (Solanum lycopersicon [Mill] Wattsd.). Karnataka Journal of Agricultural Sciences, 23(3), 536-537.

Bello, O. B., \& Olaoye, G. (2009). Combining ability for maize grain yield and other agronomic characters in a typical southern guinea savanna ecology of Nigeria. African Journal of Biotechnology, 8(11), 2518-2522.

Bello, O. B., Abdulmaliq, S. Y., Afolabi, M. S., \& Ige, S. A. (2010). Correlation and path coefficient analysis of yield and agronomic characters among open pollinated maize varieties and their F1 hybrids in a diallel cross. African Journal of Biotechnology, 9(18), 2633-2639. 
Bhagowati, R. R., \& Saikia, M. (2003). Character association and path coefficient analysis for yield attributes in open pollinated and hybrid true potato seed populations. Crop Research, 26(2), 286-290.

Bhatt, G. H. (1973). Significance of path coefficient analysis in determining the nature of character association. Euphytica, 22, 338-343. http://dx.doi.org/10.1007/BF00022643

Bodende, J. G. (2002). Path coefficient and correlation studies in tomato (Lycopersicon esculentum Mill.). Moor Journal of Agricultural Research, 61(4), 327-330.

Buckseth, T., Sharma, M. K., \& Thakur, K. S. (2012). Genetic diversity and path analysis in tomato (Solanum lycopersicum L.). Vegetable Science, 39(2), 221-223.

Chandra, Y. Y., Sanjay, K., \& Raghvendra, S. (2010). Correlation coefficient and path analysis in cucumber (Cucumis sativus L.). Progressive Horticulture, 42, 171-75.

Clewer, A. G., \& Scarisbrick, D. H. (2001). Practical statistics and experimental design for plant and crop science (p. 346). John Wiley \& Sons Ltd., New York.

Co-State Software. (2004). User's Manual Version. Cohort Tusson, Arizona, USA. Retrieved from http://www.cohort.com

Cramer, C. S., \& Wehner, T. C. (1998). Fruit yield and yield component means and correlations of four slicing cucumber populations improved through six to ten cycles of recurrent selection. Journal of American Society of Horticultural Science, 123, 388-395.

Cramer, C. S., \& Wehner, T. C. (2000). Path analysis of the correlation between fruit number and plant traits of cucumber populations. HortScience, 35, 708-711.

Dar, R. A., \& Sharma, J. P. (2011). Genetic variability studies of yield and quality traits in tomato (Lycopersicon esculentum Mill). International Journal of Plant Breeding and Genetics, 5(2), 168-174. http://dx.doi.org/10.3923/ijpbg.2011.168.174

Dar, R. A., Sharma, J. P., Gupta, R. K., \& Chopra, S. (2011). Studies on correlation and path analysis for yield and physic-chemical traits in tomato (Lycopersicon esculentum Mill). Vegetos, 24(2), 136-141.

Dewey, D. R., \& Lu, K. H. (1959). A correlation and path coefficient analysis of components of crested wheatgrass $\begin{array}{lllll}\text { seed } & \text { Agroduction. }\end{array}$ http://dx.doi.org/10.2134/agronj1959.00021962005100090002x

Dhankar, S. K., Dhankhar, B. S., \& Sharma, N. K. (2001). Correlation and path analysis in tomato under normal and high temperature conditions. Haryana Journal of Horticultural Sciences, 30(1-2), 89-92.

Dhankhar, S. K., \& Dhankar, S. S. (2006). Variability, heritability, correlation and path coefficient studies in tomato. Haryana Journal of Horticultural Sciences, 35(1\&2), 179-181.

Dudi, B. S., \& Kalloo, G. (1982). Correlation and path analysis studies in tomato. Haryana Journal of Horticultural Sciences, 11, 122-126.

FAO. (2012). Food and Agriculture Organization of the United Nations. Retrieved from http://www.faostat.fao.org

Ghosh, K. P., Islam, A. K. M. A., Mian, M. A. K., \& Hossain, M. M. (2010). Variability and character association in F2 segregating population of different commercial hybrids of tomato (Solanum lycopersicum L.). Journal of Applied Sciences and Environmental Management, 14(2), 91-95. http://dx.doi.org/10.4314/jasem.v14i2.57871

Giovannucci, E., Rimm, E. B., Liu, Y., Stampfer, M. J., \& Willett, W. C. (2002). A prospective study of tomato products, lycopene, and prostate cancer risk. Journal of the National Cancer Institute, 94, 391-398. http://dx.doi.org/10.1093/jnci/94.5.391

Golabadi, M., Eghtedary, A. R., \& Golkar, P. (2013). Relationships between different horticultural traits in (Cucumis sativus L.) genotypes with multivariate analysis. SABRAO Journal of Breeding and Genetics, 45, 447-457.

Golani, I. J., Mehta, D. R., Purohit, V. L., Pandya, H. M., \& Kanzariya, M. V. (2007). Genetic variability, correlation and path coefficient studies in tomato. Indian Journal of Agricultural Research, 41(2), 146-149.

Hannan, M. M., Ahmed, M. B., Razvy, M. A., Karim, R., Khatun, M., Haydar, A., ... Roy, U. K. (2007b). Heterosis and correlation of yield and yield components in tomato (Lycopersicon esculentum Mill.). American-Eurasian Journal of Scientific Research, 2(2), 146-150. 
Hannan, M. M., Biswas, M. K., Ahmed, M. B., Hossain, M., \& Islam, R. (2007a). Combining ability analysis of yield and yield components in tomato (Lycopersicon esculentum Mill.). Turkish Journal of Botany, 31(6), 559-563.

Harer, P. N., Lad, D. B., \& Bhor, T. J. (2003). Correlation and path analysis studies in tomato. Journal of Maharashtra Agricultural Universities, 27(3), 302-303.

Haydar, A., Mandal, M. A., Ahmed, M. B., Hannan, M. M., Karim, R., Razvy, M. A., ... Salahin, M. (2007). Studies on genetic variability and interrelationship among the different traits in tomato (L. esculentum Mill.). Middle-East Journal of Scientific Research, 2(3-4), 139-142.

Hazarika, M. H., \& Das, P. K. (1998). Genetic variability and correlation in fruit characters of tomato (Lycopersicon esculentum Mill.). Annual of Agricultural Research, 19(1), 77-80.

He, C., Poysa, V., \& Yu, K. (2003). Development and characterization of simple sequence repeat (SSR) markers and their use in determining relationships among Lycopersicon esculentum cultivars. Theoretical and Applied Genetics, 106, 363-373.

Hidayatullah, J. S. A., Ghafoor, A., \& Mahmood, T. (2008). Path coefficient analysis of yield component in tomato (Lycopersicon esculentum). Pakistan Journal of Botany, 40(2), 627-635.

Indu Rani, C., Muthuvel, I., \& Veeraragavathatham, D. (2010). Correlation and path coefficient for yield components and quality traits in tomato (Lycopersicon esculentum Mill.). Agricultural Science Digest, 30(1), 11-14.

Islam, B. M. R., Ivy, N. A., Rasul, M. G., \& Zakaria, M. (2010). Character association and path analysis of exotic tomato (Solanum lycopersicum L.) genotypes. Bangladesh Journal of Plant Breeding and Genetics, 23(1), $13-18$.

Islam, M. S., \& Khan, S. (1991). Variability and character association in tomato (Lycopersicon esculentum Mill). Bangladesh Journal of Plant Breeding and Genetics, 4(1-2), 49-53.

Izge, A. U., Garba, Y. M., \& Sodangi, I. A. (2012). Correlation and path coefficient analysis of tomato (Lycopersicon lycopersicum L. Karst) under fruit worm (Heliothis Zea Buddie) infestation in a line $\times$ tester. Journal of Environmental Issues and Agriculture in Developing Countries, 4(1), 24-30.

Jabeen, N., Sofi, P. A., \& Wani, S. A. (2009). Character association in Chilli (Capsicum annuum L.). Revista UDO Agrícola, 9(3), 487-490.

Jenkins, J. A. (1948). The origin of cultivated tomato. Economic Botany, $2, \quad 379$. http://dx.doi.org/10.1007/BF02859492

Jilani, M. S., Waseem, K., Ameer, K., Jilani, T. A., Kiran, M., Alizia, A. H., \& Parveen, A. (2013). Evaluation of elite tomato cultivars under agroclimatic conditions of Dera Ismail Khan. Pakistan Journal of Agricultural Sciences, 50, 17-21.

Joshi, A., Vikram, A., \& Thakur, M. C. (2004). Studies on genetic variability, correlation and path analysis of yield and physic-chemical traits in tomato. Progressive Horticulture, 36, 51-58.

Joshi, G. C., \& Choudhury, B. (1981). Screening of Lycopersicon and Solanum species for resistance to leaf curl virus. Vegetable Science, 8, 45-50.

Kalloo, G., Banerjee, M. K., Tewari, R. N., \& Pachauri, D. C. (2001). Tomato. In S. Thamburaj, \& N. Singh (Ed.), Textbook of Vegetables, Tuber Crops and Spices (pp. 10-29). Indian Council of Agricultural Research, New Delhi, India.

Kanyomeka, L., \& Shivute, B. (2005). Influence of pruning on tomato production under controlled environments. Agricultura Tropicaet Subtropica, 32(2), 79-81.

Kaushik, S. K., Tomar, D. S., \& Dixit, A. K. (2011). Genetics of fruit yield and it's contributing characters in tomato (Solanum lycopersicom). Journal of Agricultural Biotechnology and Sustainable Development, 3(10), 209-213. http://dx.doi.org/10.5897/JABSD11.027

Khan, M. H., \& Dar, A. N. (2010). Correlation and path coefficient analysis of some quantitative traits in wheat. African Crop Science Journal, 18(1), 9-14. http://dx.doi.org/10.4314/acsj.v18i1.54188

Khapte, P. S., \& Jansirani, P. (2014). Correlation and path coefficient analysis in tomato (Solanum lycopersicum L.). Electronic Journal of Plant Breeding, 5(2), 300-304.

Kumar, M., \& Dudi, B. S. (2011). Study of correlation for yield and quality characters in tomato (Lycopersicon 
esculentum Mill.). Electronic Journal of Plant Breeding, 2(3), 453-460.

Kumar, R., Ram, C. N., Yadav, G. C., Deo, C., Vimal, S. C., \& Bhartiya, H. D. (2014). Studies on correlation and path coefficient analysis in tomato (Solanum lycopersicon L.). Plant Archives, 14(1), 443-447.

Kumar, V. R. A., Thakur, M. C., \& Hedau, N. K. (2003). Correlation and path coefficient analysis in tomato (Lycopersicon esculentum Mill.). Annals of Agricultural Research, 24(1), 175-177.

Kumari, S., \& Sharma, M. K. (2013). Genetic variability studies in tomato (Solanum lycopersicum L.). Vegetable Science, 40(1), 83-86.

Lakshmi, K., \& Mani, V. P. (2004). Association and contribution of different characters towards fruit yield in tomato (Lycopersicon esculentum Mill.). Indian Journal of Horticulture, 61(4), 327-330.

Lungu, M. D. (1978). Classifying winter wheat environments into adaptive zones as a basis for recommending a reduction in the number of international winter wheat performance nursery test sites (M.Sc. thesis). University of Nebraska, Lincoln.

Mageswari, K., Natarajan, S., \& Thamburaj, S. (1999). Causal influence of component traits on yield in hybrids of tomato. South Indian Horticulture, 47(1-6), 179-181.

Mahapatra, A. S., Singh, A. K., Vani, V. M., Mishra, R., Kumar, H., \& Rajkumar, B. V. (2013). Inter-relationship for various components and path coefficient analysis in tomato (Lycopersicon esculentum Mill). International Journal of Current Microbiology and Applied Sciences, 2(9), 147-152.

Maitidevi, M., \& Kathmmandu, M. (2008). Product chain study tomato (p. 480). Ministry of Agriculture and Cooperatives, Project Management Unit, Biratnagar, Nepal.

Maurya, V., Singh, A. K., Rai, V. K., \& Mishra, R. (2011). Genetic variability, correlation and path coefficient analysis of tomato (Lycopersicon esculentum Mill.). Environment and Ecology, 29(3), 1076-1081.

McGiffen, M. E., Pantone, D. J., \& Masiunas, J. B. (1994). Path analysis of tomato yield components in relation to competition with black and eastern black nightshade. Journal of American Society of Horticultural Science, 119, 6-11.

Mohanty, B. K. (2002b). Studies on variability, heritability, interrelationship and path analysis in tomato. Annals of Agricultural Research, 23(1), 65-69.

Mohanty, B. K. (2002a). Variability, heritability, correlation and path coefficient studies in tomato. Haryana Journal of Horticultural Sciences, 31(3-4), 230-233.

Monamodi, E. L., Lungu, D. M., \& Fite, G. L. (2013). Analysis of fruit yield and its components in determinate tomato (Lycopersicon lycopersci) using correlation and path coefficient. Botswana Journal of Agriculture and Applied Sciences, 9(1), 29-40.

Moya, C., Alvarez, M., Varela, M., \& Mesa, M. E. (1996). Estimates of genetic-statistical parameters in three different groups of tomato (Lycopersicon esculentum Mill.) varieties growing in organoponics. Cultivos Tropicales, 17, 67-71.

Muhammad, B. A., Muhammad, R., Muhammad, S. T., Amer, H., Tariq, M., \& Muhammad, S. A. (2003). Character association and path coefficient analysis of grain yield and yield components in maize. Pakistan Journal of Biological Sciences, 6(2), 136-138. http://dx.doi.org/10.3923/pjbs.2003.136.138

Naika, S., de Jeude, J. L., de Goffau, M., Hilmi, M., \& van Dam, B. (2005). Cultivation of Tomato: Production, processing and marketing (p. 92). Agromisa Foundation and CTA, Wageningen.

Nwosu, D. J., Onakoya, O. A., Okere, A. U., Babatunde, A. O., \& Popoola, A. F. (2014). Genetic variability and correlations in rainfed tomato (Solanum spp.) accessions in Ibadan, Nigeria. Greener Journal of Agricultural Sciences, 4(5), 211-219. http://dx.doi.org/10.15580/GJAS.2014.5.031014141

Ogwulumba, S. I., \& Ugwuoke, K. I. (2013). Coefficient and path analyses of the impact of root galls caused by Meloidogyne javanica on some growth and yield parameters of tomato (Solanum lycopersicum). International Journal of Plant and Soil Science, 2(2), 222-229. http://dx.doi.org/10.9734/IJPSS/2013/3510

Padda, D. S., Saimbhi, M. S., \& Singh, K. (1971). Genotypic and phenotypic variabilities and correlation in quality characters in tomato (Lycopersicon esculentum Mill.). Indian Journal Agricultural Sciences, 41, 199-202.

Panse, V. G., \& Sukhatme, P. V. (1985). Statistical Methods for Agricultural Workers (2nd ed., p. 381). Indian Council of Agricultural Research, New Delhi. 
Prasad, V. S. R. K., \& Rai, M. (1999). Genetic variation, component association and direct and indirect selections in some exotic tomato germplasm. Indian Journal of Horticulture, 56(3), 262-266.

Rani, I., Veeraragavathatham, D., \& Sanjutha, D. (2008). Studies on correlation and path coefficient analysis on yield attributes in root knot nematodes resistant F1 hybrids of tomato. Journal of Applied Sciences Research, 4, 287-295.

Rathod, S. J. (1997). Evaluation of tomato genotypes for productivity and processing traits during late rabi season (M.Sc. (Agri.) thesis). University of Agricultural Science, Dharwad (India).

Reddy, B. R., Reddy, M. P., Reddy, D. S., \& Begum, H. (2013). Correlation and path analysis studies for yield and quality traits in tomato (Solanum lycopersicum L.). IOSR Journal of Agriculture and Veterinary Science (IOSR-JAVS), 4(4), 56-59. http://dx.doi.org/10.9790/2380-0445659

Rick, C. M. (1969). Origin of cultivated tomato, current status of the problem (p. 180). Abstract XI International Botanical Congress.

Sainju, M. U., Dris, R., \& Singh, B. (2003). Mineral nutrition of tomato. Food Agriculture and Environment, 1(2), 176-183.

Saleem, M. Y., Iqbal, Q., \& Asghar, M. (2013). Genetic variability, heritability, character association and path analysis in F1 hybrids of tomato. Pakistan Journal of Agricultural Sciences, 50(4), 649-653.

Sankari, A. (2000). Studies on the development of F1 hybrids is tomato (Lycopersicon esculentum Mill.) with high yield and resistance to tomato leaf curl virus (Ph.D. thesis). Tamil Nadu Agricultural University, Coimbatore.

Sharma, K. C., \& Verma, S. (2000). Path coefficient analysis in tomato (Lycopersicon esculentum). Indian Journal of Agricultural Sciences, 70, 700-702.

Singh, A. K., \& Raj, N. (2004). Variability studies in tomato under cold arid condition of Ladakh. Horticulture Journal, 17, 67-72.

Singh, B. D. (2013). Plant Breeding Principles and Methods (p. 923). Kalyani Publisher, New Delhi India.

Singh, D. N., Sahu, A., \& Parida, A. K. (1997). Genetic variability and correlation studies in tomato (Lycopersicon esculentum Mill.). Environment and Ecology, 15(1), 117-121.

Singh, H., \& Cheema, D. S. (2005). Studies on genetic variability and heritability for quality traits of tomato (Lycopersicon esculentum Mill.) under heat stress conditions. Journal of Applied Horticulture, 7(1), 55-57.

Singh, P. K., Singh, R. K., \& Saha, B. C. (1989). Correlation and path analysis in tomato (Lycopersicon esculentum Mill.). Annals of Agricultural Research, 10, 120-124.

Singh, R. K., \& Chaudhary, B. D. (1977). Biometrical Methods in Quantitative Genetic Analysis. New Delhi: Kalyani Publishers.

Sivaprasad, K. (2008). Genetic variability and correlation studies in biparental mating populations of tomato (Lycopersicon esculentum Mill.). Wettsd (M.Sc. (Agri.) thesis). University of Agricultural Science, Dharwad India.

Solieman, T. H. I., El-Gabry, M. A. H., \& Abido, A. I. (2013). Heterosis, potence ratio and correlation of some important characters in tomato (Solanum lycopersicum L.). Scientia Horticulturae, 150, 25-30. http://dx.doi.org/10.1016/j.scienta.2012.10.024

Sood, S., Sood, R., Sagar, V., \& Sharma, K. C. (2009). Genetic variation and association analysis for fruit yield, agronomic and quality characters in bell pepper. International Journal of Vegetable Science, 15(3), 272-284, http://dx.doi.org/10.1080/19315260902875822

Souza, L. M., Melo, P. C. T., Luders, R. R., \& Melo, A. M. T. (2012). Correlations between yield and fruit quality characteristics of fresh market tomatoes. Horticultura Brasileira, 30, 627-631. http://dx.doi.org/10.1590/S0102-05362012000400011

Susic, Z., Pavlovic, N., Cvikic, D., \& Sretenovic-Rajicic, T. (2002). Studies of correlation between yield and fruit characteristics of (Lycopersicon esculentum Mill.) hybrids and their parental genotypes. Acta Horticulturae, 579, 163-166.

Tasisa, J., Belew, D., \& Bantte, K. (2012). Genetic association analysis among some traits of tomato (Lycopersicon esculentum Mill.) genotypes in West Showa, Ethiopia. International Journal of Plant Breeding and Genetics, 6(3), 129-139. http://dx.doi.org/10.3923/ijpbg.2012.129.139 
Thangamani, C., \& Jansirani, P. (2012). Correlation and path coefficient analysis studies on yield and attributing characters in brinjal (Solanum melongena L.). Electronic Journal of Plant Breeding, 3(3), 939-944.

Tiwari, J. K., \& Upadhyay, D. (2011). Correlation and path-coefficient studies in tomato (Lycopersicon esculentum Mill.). Research Journal of Agricultural Sciences, 2(1), 63-68.

Tuncturk, M., \& ÇiftÇi, V. (2005). Selection criteria for potato Breeding. Asian Journal of Plant Science, 4, 27-30. http://dx.doi.org/10.3923/ajps.2005.27.30

Ukkund, K. C., Patil, M. P., Madalageri, M. B., Mulage, R., \& Jagadeesh, R. C. (2007). Character association and path analysis studies in green chilli for yield and yield attributes (Capsicum annuum L.). Karnataka Journal of Agricultural Sciences, 20(1), 99-101.

Verma, S. K., \& Sarnaik, D. A. (2000). Path analysis of yield components in tomato (Lycopersicon esculentum Mill.). Journal of Applied Biology, 10(2), 136-138.

Vikram, A., \& Kohli, U. K. (1998). Genectic variability, correlation and path analysis in tomato. Journal of Hill Research, 11, 107-111.

Wright, S. (1921). Correlation and causation. Journal of Agricultural Research, 20, 557-585.

Yadav, D. S., \& Singh, S. P. (1998). Correlation and path analysis in tomato. Journal of Hill Research, 11(2), 207-210.

Yin, M., \& Cui, H. (1994). Analysis of component traits for early yield in cucumber. Cucurbit Genetics Cooperative Report, 17, 27-29.

Zecevic, V., Knezevic, D., \& Micanovic, D. (2004). Genetic correlations and path coefficient analysis of yield and quality components in wheat (Triticum aestivum L.). Genetika, 36(1), 13-21. http://dx.doi.org/10.2298/GENSR0401013Z

Zhang, M., \& Cui, H. (1994). Some morphological parameters involving the mechanism of early yield in cucumber. Cucurbit Genetics Cooperative Report, 17, 24-26.

\section{Copyrights}

Copyright for this article is retained by the author(s), with first publication rights granted to the journal.

This is an open-access article distributed under the terms and conditions of the Creative Commons Attribution license (http://creativecommons.org/licenses/by/3.0/). 